\title{
Principlism in the daily practice of family medicine
}

Ana Silva, ${ }^{1}$ Hernâni Caniço, ${ }^{2}$ Susana Rosa Lopes, ${ }^{2}$ Margarida Silvestre ${ }^{3}$

\begin{abstract}
Introduction: Principlism, from Tom Beauchamp and James Childress, is the most widely accepted theory in biomedical ethics. It is based on four principles: beneficence, non-maleficence, autonomy, and justice. These are part of a common moral serving general action guides to any clinician, including the family doctor. The main purposes of this review are to describe how Principlism can be applied to daily general practice and reflect on how bioethics' principles can improve the physician-patient relationship.

Methods: We developed an integrative literature review, including conventions, declarations, treaties, textbooks, and scientific research articles. Three medical databases were selected to search through the medical literature with specific inclusion criteria. From a total of 2,352 potential articles, 161 were read and 21 were included in this review. The results were grouped into four categories: family medicine and the physician-patient relationship; respect for autonomy; non-maleficence and beneficence; and justice.

Results: Family doctors play their professional role by promoting health, preventing disease, and providing cure, care, or palliation. This area may be faced with ethical dilemmas including the moment of obtaining informed consent, medical confidentiality, disease prevention, and the choice of complementary diagnostic tests and therapeutics. All these moral dilemmas arise in the context of a single interpersonal relationship, which is possibly the most therapeutic aspect of medical consultation.

Conclusions: Despite all the technological innovation, moral conduct, and principles governing the profession of family doctors remains faithful to the principles of the FM specialty. In a context of a dehumanization threat and global discontent, it is essential to foster a growing humanization of primary health care and recover ethical values, to achieve an optimization of the physician-patient relationship, to deepen the level of understanding of "patient's needs and values" and finally to meet their expectations.
\end{abstract}

Keywords: Bioethics; Principlism; Beneficence; Physician-patient relationship; General practice.

\section{INTRODUCTION}

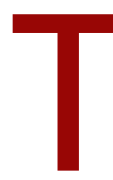

here are several ethical theories applicable to medical practice, as principlism, casuistic, utilitarism, and the ethics of virtues. According to the casuistic theory, each case is analyzed based on a previous decision taken in similar cases, while according to utilitarism, the right action in any circumstance is the act that produces the best overall result (principle of utility) and concentrates on the value of well-being, regardless to the circumstances, agents, intentions, acts, and means..$^{1-2}$ The ethics of virtues gi-

1. USF Moliceiro, ACES Baixo Vouga, Aveiro, Portugal.

2. UCSP Dr. Manuel Cunha, ACeS Baixo Mondego, Coimbra, Portugal.

3. Instituto de Bioética, Faculdade de Medicina da Universidade de Coimbra, Coimbra, Portugal. ves a preeminent place to the moral agent with moral virtues that may be understood as morally praiseworthy character traits. ${ }^{2}$ However, this can be considered an incomplete ethical theory because it does not provide a clear decision model for making moral decisions. In other words, it does not really help if one encounters an ethical dilemma and isn $t$ able to give any form of guidance on what to do as principlism suggests. Therefore, it was chosen to develop Principlism, whose principles are part of a common moral and try to give a general action guide to solve some ethical dilemmas.

In spite of some criticisms, Tom Beauchamp and James Childress's principlism is currently the theory of greater acceptance in biomedical ethics. ${ }^{3-5}$ It is based on four principles, with a prima facie character: respect for autonomy ('the person chooses'); non-maleficence ('avoiding damage'); beneficence ('doing good') and 
justice ('to prioritize with equity', making judicious use of available resources) ${ }^{6-7}$ According to the Code of Ethics of the Portuguese Medical Association, the fundamental ethical principles constitute the pillars of the medical profession, delimiting ('constraining') the behavioral conducts that this code introduces and which guide the different aspects of human relations that are established during the medical profession. ${ }^{8}$ The dayto-day life of the family doctor (FM) is full of moral dilemmas, due to a frequently difficult and intense interpersonal relationship between the physician and the patient, in which the principles constitute important general guidelines for action.

Nowadays the medical profession is a frequent target of criticism and the doctor's personal relationship with the patient has deteriorated due to this fact. ${ }^{9}$ Santiago Montero states that family medicine (FM) constitutes an 'unacceptable social caricature', which needs to be urgently recovered regarding human promotion, contrary to the reference of this specialty as a 'mere filter of banalities' and the demoralization of the professionals who carry it out. ${ }^{10}$ In a society described, by some authors, as increasingly dehumanized and dehumanizing, ${ }^{11}$ it is vital to recovering ethical values, moral rights and duties, as well as virtues. ${ }^{1}$

Thus, in a context of increasing technologization of care and global discontent, ${ }^{11}$ it is fundamental to stop and reflect on how ethics can help overcome these difficulties. This paper, therefore, aims to address the mainstream bioethics proposed by Beauchamp and Childress and its daily application in the practice of FM, referring to the most common ethical problems in primary health care and proposing how bioethics' principles could improve the physician-patient relationship (PPR).

\section{METHODS}

This integrative literature review was based on conventions, declarations, treaties, textbooks, and research articles. The electronic research was done in three databases: LILACS, SciELO, and MEDLINE, the latter through PubMed NCBI. For this articles' research, we used the following descriptors/MeSH terms: 'Principle Based Ethics' and 'General Practice'; 'Clinical Ethics' and 'Physician-Patient Relationship'; 'Bioethics' and 'Principlism'.
The articles' inclusion criteria were as follows: to be published between January 2005 and November 2017 in Portuguese, English, or Spanish language; to address the application of at least one of the bioethics' principles (autonomy, beneficence, non-maleficence, and justice) on a day-to-day PPR, with an emphasis on the FM area. Reference lists from relevant review articles were also searched. Papers without abstracts available for analysis in used databases and published in other languages were excluded. Of 2352 potential articles, 161 were read and 21 were included in the integrative literature review.

The results concerning the relationship between bioethics' principles and clinical practice in FM were grouped into four categories: FM and the PPR; respect for autonomy; non-maleficence and beneficence; and justice.

\section{RESULTS}

\section{Family medicine and the physician-patient relationship}

FM is considered the most personal medical discipline, addressing a biopsychosocial strategy on the PPR, and integrating simultaneously new evolutionary technologies. ${ }^{12}$ According to Rakel, FM's main field of action encompasses first-contact care, which includes continuity and integral care, and assumes responsibility to the individual and the community, for a highly personalized kind of care. ${ }^{13-14}$

Family doctors govern their job and way of acting, influenced by a set of values, attitudes, and principles: they act as a coordinator and integrator of all health resources; ${ }^{14}$ acts as a confidant, a tutor, and an advocate, explaining the causes and implications of the disease to patients and their families; ${ }^{14}$ acts as a defender of rights, interests, and needs of patients needing a strong sense of responsibility. ${ }^{13}$ At this level of constant concern for others and their welfare, arises the need and justification for a person-centered medicine (PCM), based on a biopsychosocial model ${ }^{9}$ that describes the key tasks of a person-centered interview as follows: building a helping relationship; the exchange of information; be considerate with responses to emotions; management of uncertainty; shared decision-making; and the empowerment of a person's self-care. ${ }^{15}$

The process of interaction between family doctor and patient is probably the most therapeutic aspect of a medical appointment because the problem is not only 
in the person but also in the relationship between people. ${ }^{15}$ The medical appointment is a diagnostic and therapeutic procedure of high technical complexity; whose success depends greatly on the quality of the PPR developed in it. ${ }^{16}$

According to the World Federation for Medical Education, dissatisfaction with PPR is one of the main causes of malaise. ${ }^{9}$ Evidence has shown that this displeasure results largely from the discrepancy between the patient's expectations and the clinician s response. Most complaints (72\%) involve insensitivity to problems or communication failures on behalf of practitioners, including lack of information, non-participation in medical decisions, and lack of empathy. ${ }^{9}$ According to Rakel, patients prefer a physician who is attentive to their needs and an "accessible" person with whom they can establish a lifelong relationship. ${ }^{14}$

\section{The application of the four principles of medical ethics on the daily life of the family medicine physician \\ Respect for autonomy}

The first principle of Beauchamp and Childress's book, PRINCIPLES OF BIOMEDICAL ETHICS, demands respect for autonomy, which implies the permanent recognition that people have the right to act in accordance with their own convictions, conceptions, values, and beliefs. ${ }^{17}$ For an act to be considered autonomous, it has to be preceded by the necessary information, the agent has to have capacity and competence to execute it, and the final decision has to be free from internal or external constraints and restrictive factors internal or external to the subject, which could prevent the physician from making their decision in a deliberate and conscientious manner. ${ }^{1}$

In the world of health care, the most important bioethical rule deriving from the principle of respect for autonomy consists in requesting the patients' informed consent to medical acts proposed to them. ${ }^{18-19}$ According to Faria-Vaz, informed consent in the context of the family doctor's practice constitutes a renewed opportunity to promote PPR, as well as the participation of patients in the decision-making process, allowing them to act as an active agent, behaving as a partner in the therapeutic process and in the health process. ${ }^{20}$ For this to happen, this author stresses the importance of avoiding, at all costs, this ethical obligation from becoming a bureaucratic administrative act, alerting for the need of communication skills and competencies on behalf of the health professional, to provide adequate and appropriate information to patients. ${ }^{20}$

The widespread use of informed consent necessarily implies the (re-) cognition of the concepts of secrecy and medical confidentiality. ${ }^{19}$ Participation by third parties (including family members, other health professionals, and students) is particularly frequent in FM consultation. ${ }^{21}$ While the participation of other family members accompanying the patient can improve the understanding by the patient of his/her problem, helping to better understand the diagnosis and treatment, in some other cases it may jeopardize the environment of privacy and confidentiality expected by the patient. ${ }^{22}$ That is, the freedom of the patient can, at times, be limited by the presence and intervention of family members.

Regarding the treatment of several members of the same family by the same family doctor, opinions differ. For Philippe Karazivan, dealing with entire families is beneficial because it allows a more comprehensive approach, in which the physician is more aware and better acquainted with the family context, helping to understand the experiences, symptoms, ideas, values, and beliefs of patients. ${ }^{23}$ In a different approach to the same issue, Charles Pless also acknowledges the importance of knowing some information about his patient's families but argues that the treatment of all members of the same family can lead to dilemmas such as confidentiality and conflict of interest. ${ }^{24}$

For Alberto Hespanhol, "one of the most peculiar characteristics of FM that distinguishes it from other specialties is the moral tension caused by the core of its mission, namely the commitment to the patient as an individual, as well as with the family as a care unit". ${ }^{25}$ This moral tension often occurs in the day-to-day life of every family doctor, especially when become aware of the existence of some serious problems, like a maltreated element in the family or harmful lifestyles, such as alcoholism, drug addiction or prostitution. ${ }^{25}$ These kinds of situations often create a conflict between the well-being of some and the autonomy of other family members who have the same physician. However, where the risk of harm to third parties is high, the duty of protection must overlap with the duty of secrecy. In this 
way, physicians should keep a critical eye on any legal requirement of breach of confidentiality, becoming aware that it may conflict with the respect for human rights that underlies medical ethics. ${ }^{26}$

In conclusion, in clinical bioethics, the right to autonomy goes far beyond freedom of choice and may conflict with the obligations of health professionals when seeking the well-being of their patients, and it may be legitimately limited by respect for other values inherent to other principles of bioethics, namely beneficence, and justice. ${ }^{1}$

\section{Non-maleficence and beneficence}

The physician's duty to keep patient information confidential has been the cornerstone of medical ethics since the time of Hippocrates, already contemplated in his Oath's more recent version. ${ }^{27}$ The International Code of Medical Ethics and the Declaration on the Rights of the Patient also address the concept of confidentiality, giving space to some exceptions in medical practice that allow a justified violation of this duty, namely when there is a real and imminent threat of harm to the patient and/or others, as in cases of HIV-positive individuals who refuse to inform their partners at risk, manifesting their intention to continue having unprotected sex. ${ }^{2}$ In these cases, the FD plays a key role in balancing the principle of autonomy with non-maleficence and beneficence, and he/she may have to break confidentiality to protect third parties, being beneficent towards them, as it is also consecrated in the Code of Ethics of the Portuguese Medical Association.

In this context, we can understand some limitations of principlism. The principles are extensively indeterminate and too abstract to determine the precise acts that we should perform. ${ }^{2}$ Furthermore, they can bring some conflicts between them and do not show the necessary specification, mainly in the orientation of specific cases. ${ }^{2}$

In health care, the maxim primum non nocere: (first, do no harm $)^{28}$ is not unusual. Regarding principlism, although the principles have a prima facie character and no hierarchy between them, the responsibility not to cause harm seems to have a greater moral weight than an imperative of beneficence. In this way, one must first prevent damage and then promote good..$^{17,19}$ So, although the lack of specifications and the need to be balanced, the principles should function as general gui- delines for the formulation of the more specific rules and take on a vital role in biomedical ethics. ${ }^{2}$

Prevention is one of FM's main lines of action. Regarding secondary prevention, screening has come to a prominent place, ${ }^{25}$ constituting a pre-symptomatic diagnostic activity, with the objective of selecting individuals who may benefit from early interventions, whose potential benefit is greater than the potential harm. ${ }^{29}$ At this level, some conflicts arise, especially between the principle of beneficence and non-maleficence, raising questions such as: To what extent does the benefit of screening go? Which cases will justify its applicability? What are the limits of its use? What are the implications of false positives and false negatives on the well-being of the patient?

If the proposal is to intervene in previously healthy people, it is essential to be sure that the intervention will produce more benefits than harms. This is not always easy to guarantee, given the heterogeneity and unpredictability of the natural history of the disease, as well as the inherent complexity to the screening process, often performed as an intervention "in the dark". ${ }^{29}$ In the practice of FM there are several examples in which these two medical ethics principles, beneficence, and non-maleficence, may point to opposing decisions whose balance may hinder decisions in clinical practice. ${ }^{30}$ These include the physical discomfort caused by the screening or attitudes practiced following the obtained result; ${ }^{29}$ the identification of cancers without clinical relevance; the psychological effects and social implications of having an asymptomatic disease, and the possibility of obtaining a false positive result. ${ }^{30}$ In other words, conducting a screening test can generate unnecessary anxiety in the patient, besides being able to be carriers of conditions that will never culminate in illness, revealing the unnecessary accomplishment of this test, as its benefits are not superior to the damages caused, on the contrary. In this context, exposing the patient to potential risks that do not bring greater benefits or screening for diseases for which there are no proven treatments yet, is ethically unjustified. ${ }^{25}$ According to some authors, potentially harmful interventions in healthy people, despite being an area of FM, would not be a priority for family physicians, due to its high complexity, the difficulty of its evaluation, the biases involved, and the ethical rigor to which they are subject in their practice. In this respect, other fundamental ingredients should be favoured, such as longitudinal integral care, health promotion, and 
disease prevention, all permeated by the spirit of quaternary prevention and health promotion. ${ }^{29}$

The concept of quaternary prevention, also known as iatrogenic prevention, aims to prevent or attenuate the excess of medical intervention, such as increasing and invasive diagnostic and therapeutic interventions. ${ }^{30}$ It is now considered that the confidence model is the most appropriate form of relationship for clinical practice, particularly in FM, translating the application of the concept of shared decision ${ }^{31}$ as a way to meet the best benefit and least harm to the patient, always respecting the autonomy of both parties involved in this relationship of trust.

Patients' referral is the key to the continuity of care, a concept closely related to FM. ${ }^{32}$ There are national and international studies referring that Portugal has the worst results in terms of information exchange between the two levels of health care, with multiple failures during this referral process leading to duplication of examinations, delays in diagnosis and treatment, the overall increase in costs, unjustified asymmetries in resource allocation, the difficulty of including patients in the decision-making process. ${ }^{32}$ Since family doctors do the initial evaluation of the situation and decide, most of the time, how the patient will be guided through the health service, has FD have great responsibility at this level and also have the duty to avoid disarticulation between different doctors and levels of care. ${ }^{32}$

\section{Justice}

Beauchamp and Childress's fourth principle, but not least important, is the principle of justice/equity that represents a concern for the equitable distribution of the scarce resources of the health system. ${ }^{30}$ One of the central aspects advocated in the Human Development Report (2014) is the conviction that "everyone has the right to access education, health care and other basic services" and that application of the principle of universality in practice requires particular attention to the most vulnerable groups, including children, adolescents and the elderly. ${ }^{33}$ The ability to deal with this vulnerability, existing at different levels and at the same time, without neglecting the application of distributive justice, is an important field of action of FD, in which several bioethical dilemmas may arise, especially when the resources cannot be distributed fairly, taking into account the vulnerabilities of each patient.
FD is also faced with other dilemmas, such as complementary diagnostic exams at the patient's request, including routine laboratory tests, radiological exams, ultrasound scans, as well as requests for exams such as computerized tomography scans or magnetic resonance imaging. ${ }^{31}$ These requests, while conveying empowerment to the patient ${ }^{31}$ may lead to the practice of defensive medicine - characterized by an exaggerated use of complementary exams, use of safer therapeutic procedures, and frequent referral of patients to other specialists - in order to protect the doctor against medical liability claims. ${ }^{34}$ However, besides inefficient in protecting the doctor, defensive medicine has severe consequences to the patient and to society, since it generates additional costs to medical practice, determines greater suffering to the patient, and causes deterioration of the doctor-patient relationship..$^{34}$ The request for exams or treatments, should be done in a shared decision model (co-decision), which implies the autonomy of both (doctor and patient). ${ }^{31}$ In a good doctor-patient relationship this can be done peacefully by explaining each diagnostic exam and therapeutic choice.

Oliver and Evans stress the role of family doctors as 'social decision makers', ${ }^{34}$ who must learn to balance their responsibility to the patient and their social responsibility, including in their considerations the appropriate use of the resources at their disposal. ${ }^{31}$ In this context, the current concept of health quality is essential, according to which a quality service is not one that meets the needs of its users at any cost, but rather the one that uses the resources in a way that is as efficient as possible, in order to match the sometimes hostile or conflicting requirements between these three different dimensions: quality for the user, professional quality and quality of management..$^{25}$

\section{CONCLUSIONS}

After analyzing several situations and contexts of the clinical practice of FD it was observed that the principles of respect for autonomy, beneficence, non-maleficence, and justice continue to be current concepts and serve as general guides for the performance of the $\mathrm{FD}$, and of all physicians in general. In this field, bioethics appears like a great deal of hope that seeks to rescue the dignity of the human being, in a holistic approach that encompasses all dimensions of the patient and 
that guarantees the maintenance of their multidimensional state of health (physical, psychic, and social), in a context of growing technology.

One of the six key tasks of a person-centered interview, the CCM model, is managing uncertainty. This does not occur simply on a purely medical approach, but also on an ethical level, especially when bioethical principles conflict, making decision making even more difficult. How can we be sure that the decision we make is the best for our patients? How can we be sure that the course of action that we consider to be the optimal one is accepted by our patients and understood as the best option by our colleagues? Is it legitimate to admit that my ethics is higher than other doctors' ethics? These are just some of the questions that emerge when we reflect on the applicability of bioethics in clinical practice and whose answers are far from definitive, immutable, and consensual.

There are some medical advances that are given as dogmas. However, as far as the human dimension, inherent in the PPR and the bioethical principles that we should respect, we are still far from finding an absolute truth about how to act before each clinical practice situation. The acquisition of acceptable forms of action and the awareness of this need are becoming more and more essential, according to the ethics of each one. At this level, the concepts of deliberation and moral decision come up, which include not only compliance with the principles in question, but also the points of view, emotions, values, and beliefs of both sides. ${ }^{36}$ In a process of moral deliberation, the physician must verify if the pondered action complies with ethical principles, has to evaluate the circumstances and consequences in order to determine whether they allow or demand an exception to the principles of medical ethics. ${ }^{36}$ The PPR is a continuous deliberative process, in which principles can conflict; in this situation, one principle should not be favoured over the other (extreme courses of action), but an intermediate course of action should be found, which respects both, although partially.

FM practice is of enormous complexity and responsibility, both to the patient, to the family, and to the community. Within this specialty, physicians may be confronted with bioethical dilemmas in various areas of practice, namely in obtaining informed consent, confidentiality, referral process, disease prevention, and distribution of limited diagnostic and therapeutic re- sources. Thus, if we want to act ethically, we must respect the principles that guide our action but also to consider its circumstances and consequences, and finally, we should integrate it with a critical self-reflection guided by morality. Through this way of acting, we can achieve an ethical, useful, and meaningful approach of our patients, always based on moral values that allow decision making of good medical and humanized care, ${ }^{1}$ without ever forgetting that the PPR is undoubtedly the essence of medical care and the main source of gratification for the clinician.

The FD, as a defender of the rights, the interests, and the needs of its patients, has an increased responsibility regarding the promotion of individual and public health, seeking not only the good of everyone but simultaneously the good of the whole society. This physician has the responsibility to dignify his profession and strive for the best quality of services rendered, without ever neglecting respect for others, considering their rights and particularities as human beings.

Regardless of the technical advances that medicine may achieve, there will always be an irreplaceable element that is the therapeutic power of PPR itself. Thus, faced with the complexity of the FM practice, there is a principle that we must not forget: "Before we become good professionals, we have to be good human beings" (unknown author).

It is more and more important to promote medical ethics training to achieve an optimization of the physician-patient relationship, to deepen the level of understanding of patient's needs, values, and expectations. Improve the patient's quality of life and satisfaction levels with health care is one of the fundamental purposes of family medicine.

\section{ACKNOWLEDGEMENTS}

We would like to thank Germana Rodrigues for providing translation services.

\section{REFERENCES}

1. Silvestre M. Enquadramento teórico. In: Silvestre M, editor. Embriões excedentários: entre a técnica, a lei e a ética. Coimbra: Coimbra Editora; 2015. p. 19-56. ISBN 9789723223293

2. Beauchamp TL, Childress JF. Principles of biomedical ethics. 6th ed. New York: Oxford University Press; 2009. ISBN 9780195335705

3. Pellegrino ED. Toward a reconstruction of medical morality. Am J Bioeth. 2006;6(2):65-71. 
4. Petry FB. Princípios de ética biomédica [resenha].ethic@.2004;3(1):87-92.

5. Williams JR. Principal features of medical ethics. In:Williams JR, editor. Medical ethics manual [homepage]. 3rd ed. Ferney-Voltaire:WMA The World Medical Association; 2015. p. 15-32. Available from: https:// www.wma.net/what-we-do/education/medical-ethics-manual/

6. Dalla MD, Lopes JM. Ética na atenção primária à saúde. In: Gusso G, Lopes JM, editors. Tratado de medicina de família e comunidade: princípios, formação e prática. Artmed; 2012. p. 98-106.

7. Simões JA. Ética nos cuidados de saúde primários. Rev Psiquiatr Cons Ligação. 2011;19:49-53.

8. Regulamento n. ${ }^{\circ} 707 / 2016$, de 21 de julho. Diário da República. $2^{a}$ Série(139).

9. Macedo AF, Azevedo MH. Relação médico-doente. In: Oliveira CF, editor. Manual de ginecologia. Coimbra: Permanyer Portugal; 2011. p. 59-79.

10. Álvarez-Montero S. Crisis en la medicina de familia: una perspectiva bioética desde la práctica diaria [Crisis in family medicine: a bioethical perspective from the routine practice].Aten Primaria. 2010;42(10):528-33. Spanish

11. Pessini L. Bioética e cuidado do bem-estar humano: ética, humanização e vocação como desafio para os profissionais da saúde. Fragm Cult. 2003;13(1):17-39.

12. Taylor RB. Medicina de família: una prática actual e futura. In: Taylor RB, editor. Medicina de familia, principios y práctica. $6^{\text {a }}$ ed. Oregon: Elsevier Masson; 2007. p. 3-9. ISBN 9788445812983

13. Lopes JM. Princípios da medicina de família e comunidade. In: Gusso G, Lopes JM, editors. Tratado de medicina de família e comunidade: princípios, formação e prática. Artmed; 2012. p. 1-11.

14. Rakel RE. Family physician. In: Rakel RE, Rakel D, editors. Textbook of family medicine. 9th ed. Philadelphia: Elsevier Saunders; 2015. p. 316.e2. ISBN 9780323239905

15. Carrió FB, Dohms M. Relação clínica na prática do médico de família. In: Gusso G, Lopes JM, editors. Tratado de medicina de família e comunidade: princípios, formação e prática. Artmed; 2012. p. 124-32.

16. Simões JA. A consulta em medicina geral e familiar [The consultation in family medicine]. Rev Port Med Geral Fam. 2009;25(2):197-8. Portuguese

17. Petry FB. Princípios ou virtudes na bioética? Controvérsia. 2005;1(1):49-65.

18. Salinsky J. Como os grupos Balint têm mudado ao longo de 57 anos: objectivos e expectativas [How Balint groups have changed over 57 years: goals and expectations]. Rev Port Med Geral Fam. 2008;24(4): 526-30. Portuguese

19. Ainslie DC. Principlism. In: Post SG, editor. Encyclopedia of bioethics. 3rd ed. MacMillan Library Reference; 2003. p. 2099-103. ISBN 9780028657790

20. Faria-Vaz A. Ética: agir e porvir [Ethics: action and the future]. Rev Port Med Geral Fam. 2009;25(5):520-1. Portuguese

21. Granja M. A consulta a três [When three are present at the consultation]. Rev Port Med Geral Fam. 2008;24(1):85-96. Portuguese

22. Campbell TL, McDaniel SH, Cole-Kelly K. Aspectos de la familia en la asistencia sanitaria. In:Taylor RB, editor. Medicina de familia, principios y práctica. $6^{a}$ ed. Oregon: Elsevier Masson; 2007. p. 30-3. ISBN 9788445812983

23. Karazivan P. Should family physicians treat members of the same family? YES. Can Fam Physician. 2011;57(4):402-4.
24. Pless C. Should family physicians treat members of the same family? NO. Can Fam Physician. 2011;57(4):402-4.

25. Hespanhol AP. Problemas éticos em medicina geral e familiar [Ethical issues in family medicine]. Rev Port Med Geral Fam. 2003;19(4):38995. Portuguese

26. Williams JR. Physicians and patients. In:Williams JR, editor. Medical ethics manual [homepage]. 3rd ed. Ferney-Voltaire:WMA The World Medical Association; 2015. p. 50-5. Available from: https://www.wma.net /what-we-do/education/medical-ethics-manual/

27. World Medical Association. WMA Declaration of Geneva [homepage]. WMA; 2017 Oct [cited 2017 Dec 15]. Available from: https://www. wma.net/policies-post/wma-declaration-of-geneva/

28. Lawrence DJ. The four principles of biomedical ethics: a foundation for current bioethical debate. J Chiropr Humanit. 2007;14:34-40.

29. Norman AH, Tesser CD. Rastreamento de doenças. In: Gusso G, Lopes JM, editors. Tratado de medicina de família e comunidade: princípios, formação e prática. Artmed; 2012. p. 521-31.

30. Hespanhol AP, Couto L, Martins C. A medicina preventiva [Preventive medicine]. Rev Port Med Geral Fam. 2008;24(1):49-64. Portuguese

31. Lourenço A. Do injustificável ao ajustado: notas sobre terapêuticas e exames complementares de diagnóstico a pedido dos doentes [Patient's requests for tests and treatments]. Rev Port Med Geral Fam. 2008;24(1):75-84. Portuguese

32. Almeida R, Braga R. Ética e relações profissionais [Ethics and professional relationships]. Rev Port Med Geral Fam. 2008;24(1):97-105. Portuguese

33. Malik K. Síntese. In: Relatório do desenvolvimento humano 2014 Sustentar o progresso humano: reduzir as vulnerabilidades e reforçar a resiliência. Nova lorque: Programa das Nações Unidas para o Desenvolvimento; 2014. p. 1-13. ISBN 9789210566698

34. Minossi JG, Silva AL. Medicina defensiva: uma prática necessária? [Defensive medicine: a necessary practice?]. Rev Col Bras Cir. 2013;40(6):494-501. Portuguese

35. Oliver A, Evans J. The paradox of promoting choice in a collectivist system. J Med Ethics. 2005;31(4):187.

36. Gracia D. Ethical case deliberation and decision making. Med Health Care Philos. 2003;6(3):227-33.

\section{CONFLICTS OF INTEREST}

The authors declare that there is no conflict of interest in this article.

\section{FUNDING}

The work reported in this article has not been the subject of any external funding (including scholarships and research).

\section{CORRESPONDING AUTHOR}

Ana Silva

E-mail: anafortunato3@gmail.com

https://orcid.org/0000-0002-3210-9321

Recebido em 16-09-2019

Aceite para publicação em 25-05-2021 


\section{RESUMO}

\section{A ÉTICA PRINCIPIALISTA EM MEDICINA GERAL E FAMILIAR}

Introdução: A ética principialista, de Tom Beauchamp e James Childress, constitui atualmente a teoria de maior aceitação na ética biomédica, fundamentada em quatro princípios: beneficência, não-maleficência, autonomia e justiça. Estes fazem parte de uma moral comum servindo de guias gerais de ação de qualquer médico, incluindo o médico de família (MF). Os principais objetivos desta revisão são descrever como o Principialismo se pode aplicar à prática diária da medicina geral e familiar (MGF) e refletir acerca de como os princípios da bioética podem melhorar a relação médico-doente (RMD).

Métodos: Foi elaborada uma revisão integrativa da literatura, incluindo convenções, declarações, tratados, livros de texto e artigos científicos de investigação. Selecionaram-se três bases de dados e foram usados critérios de inclusão específicos. De um total de 2.352 artigos, 161 foram lidos e 21 incluídos. Os resultados foram agrupados em quatro categorias: MGF e RMD; respeito pela autonomia; não maleficência e beneficência; e justiça.

Resultados: Os MF desempenham o seu papel profissional promovendo a saúde, prevenindo a doença e providenciando cura, cuidados ou paliação. Na prática clínica apresentam-se dilemas morais ao nível da obtenção do consentimento informado, da confidencialidade, da prevenção da doença e da escolha dos exames complementares diagnósticos e terapêuticos. Estes surgem no contexto de uma relação interpessoal única, que é possivelmente o aspeto mais terapêutico da consulta.

Conclusões: Apesar de toda a inovação tecnológica, a conduta moral e de princípios que rege a profissão dos MF continua fiel aos princípios da especialidade de MGF. Numa era de desumanização e de descontentamento global, torna-se imprescindível fomentar uma crescente humanização dos cuidados de saúde primários e recuperar valores éticos, no sentido de alcançar uma otimização da relação médico-doente, aprofundando o nível de compreensão da "posição de doente" e indo ao encontro das suas expectativas.

Palavras-chave: Bioética; Principialismo; Beneficência; Relação médico-doente; Medicina geral e familiar. 